
LOCAL AUTHORITIES

Authors David King, (principal author) Professor, Department of Economics University of Stirling; also consultant on local government and its finance to the OECD and the World Bank.

Matthew Pashley, Research assistant, Department of Economics, University of Stirling.

Rob Ball, Professor, Department of Management \& Organisation, University of Stirling.

Contact (Principal author) Professor David King, Department of Economics, University of Stirling, Stirling FK9 4LA;

E-mail: dnk1@stir.ac.uk; Tel: 01786 467475; Fax: 01786467469

DATE

December 2005

ABSTRACT

Scottish citizens benefit from 19\% more public spending per head than English citizens. The 'Barnett formula' is slowly reducing the gap, but very little is known about the countries' relative needs and hence about how far the present gap is defensible: the aim of this paper is to throw some light on the countries' relative needs. We begin with the complex formulae that the Westminster government uses to assess the spending needs of English local authorities, and we use these English formulae to assess the needs of Scottish local authorities for three major blocks of local services. These formulae suggest that Scotland needs 6.4\% more per head than England for environmental, protective and cultural services, $8.1 \%$ more for highway maintenance, and between $24.3 \%$ and $35.3 \%$ more for fire services. We also combine these results with those of two other papers concerned with local education and social services to show that these English formulae put Scotland's per capita needs for local government services as a whole at about 6\% above England's. However, we then compare the relative needs of Scottish local authorities as assessed by the English formulae with their relative needs as assessed by the Scottish needs formulae that are currently used by Holyrood, and we find major differences. This suggests either that at least one country uses seriously flawed formulae to assess needs, or that the two countries have different conceptions of need.

JEL CLASSIFICATION NUMBERS: H0, H7, R5.

\title{
ACRONYMS
}

\author{
ACA Area Cost Adjustment \\ EPCS Environmental, Protective and Cultural Services \\ FSS Formula Spending Share \\ GAE Grant Aided Expenditure \\ IBJSA Income Based Jobseeker's Allowance \\ IS Income Support \\ LA Local Authority \\ ODPM Office of the Deputy Prime Minister \\ OS Ordnance Survey \\ SE Scottish Executive
}




\section{THE ENVRONMENTAL SPENDING NEEDS OF SCOTLAND'S LOCAL AUTHORITIES}

\section{Introduction}

Individuals, communities and enterprises in Scotland enjoy a much higher level of public spending than applies to their counterparts in England. In 2002-03, for example, they received about $19 \%$ more current expenditure per head. ${ }^{1}$ It might be thought that this difference has arisen as a result of applying uniform policies across the UK, so that it reflected a consistent UK-wide estimate of relative spending needs.

The situation is less clear-cut. Just under half this public spending relates to transfers concerned with social protection. These transfers, which include programmes such as state pensions and job-seekers' allowance, are indeed made on the basis of UK-wide policies, so any excess that Scotland enjoys over England must reflect a government view that Scotland has higher needs. Scotland actually receives about $12 \%$ more per head on these transfers.

But just over half of this public spending concerns public services, and here Scotland enjoys 25\% more spending per head than England. Since May 1999, most of these services have been the responsibility of the new Scottish Parliament in Holyrood. Until then, most of them were actually handled by the Scottish Office - a department of the Westminster government rather than by the ministries which looked after the relevant services in England.

The funding arrangements for the Scottish Office did not reflect a detailed assessment of Scotland's relative spending needs. Rather, they were based on the 'Barnett formula', and this formula is also used today to determine the bulk of the central government funds allocated to Holyrood. This formula is outlined briefly in Section II. Section II also explains that because Scotland's higher per capita service spending is a matter of controversy. Some argue that Scotland deserves less spending, but others argue the converse.

This controversy can be resolved only by comparing the spending needs for public services in the two countries. The current paper is one of three where we compare their needs for different local services. These papers give the only detailed comparison of the countries' needs for public services that has ever been made, and so give a unique insight into a major debate. By referring to all three, we are able to draw some important overall conclusions.

Of course, different people hold different views about needs. So if we devised our own formulae for assessing needs, then our formulae could be challenged and any comparison based on them dismissed. But we do not have to devise assessments for relative need in different areas for local authority (LA) services, because each LA's relative needs are already assessed, in England by the Office of the Deputy Prime Minister (ODPM) and in Scotland by the Scottish Executive (SE). The ODPM and SE use their own different formulae, but these formulae have been developed over many years and can be taken to have some support. So comparisons based on them should be harder to dismiss. Although using these formulae means that we consider only local government services, these between them are the most important ones, for they account for some $60 \%$ of spending on government services.

Section III explains that in this paper we compare needs to spend on (a) environmental, protective and cultural services (EPCS), (b) highway maintenance, and (c) fire services. 
Taken together with our two other papers, we have now covered all local services except police where the official formulae are so complex that they would require a paper for themselves; fortunately, police services account for only $7 \%$ of local spending, so their omission does not significantly distort the overall picture.

Section IV looks at the contexts in which the English and Scottish formulae operate. Section V gives a brief overview of the two formulae. Sections VI, VII and VIII respectively apply to Scotland the English formulae for EPCS, highway maintenance and fire services, to see if these English formulae suggest that Scotland has higher per capita needs than England. Section IX compares the relative needs of Scotland's local authorities as they would be assessed by the English formulae, if they applied in Scotland, with their relative needs as currently assessed by the Scottish formulae; this enables us to see if the two formulae agree on which authorities are most needy and which are the least needy. Section X gives our conclusions from this paper and our two other papers (King et al, 2004 and 2006).

\section{The Barnett formula}

The origins of the Barnett formula can be traced back to the Victorian chancellor George Goschen. $^{2}$ He created a formula by which Scotland was allocated $11 \%$ of public spending, Ireland 9\%, and England and Wales 80\%. The basis for these shares is uncertain. It may have reflected the countries' 1881 populations or their shares of probate duties paid to the Exchequer. It certainly did not reflect a careful analysis of the countries' spending needs.

This formula was never applied to all public services, but it was used for some until 1959. From then until 1978, no set formula was used, but in 1978, when much attention was paid to the devolution debate, the Chief Secretary to the Treasury Joel Barnett proposed the formula which bears his name. By 1978, spending per head in Scotland and Wales was far higher than in England. The idea behind the Barnett formula was to reduce this difference over time. Using 1976 population figures, the formula allowed that whenever public spending in Great Britain rose by $£ 100, £ 85$ should go to England, $£ 10$ to Scotland and $£ 5$ to Wales.

Because each increase in spending was allocated on a population basis, each increase reduced the extent to which spending per head in Scotland exceeded that in England. For example, suppose for simplicity that one year public spending in Great Britain was £100bn, with Scotland getting £13bn and England getting £82bn. And suppose Scotland's population was 5 million while England's was 42.5 million. Then spending per head was £2,600 in Scotland and £1,929 in England; so it was 35\% more in Scotland. Now suppose that spending doubled over a period of years. Then, under the Barnett formula, Scotland would receive £10bn of the extra $£ 100$ bn while England would receive £85bn. So spending in Scotland would rise by $77 \%$ from £13bn to £23bn, while spending in England would rise by $104 \%$ from £82bn to $£ 167 \mathrm{bn}$. Public spending per head would end up at £4,600 per head in Scotland and £3,924 per head in England; so it would now be just 17\% higher in Scotland.

Later, Northern Ireland was introduced into the formula. Also, in 1992 and each year since 1999-2000, slight changes to the formula have been made to reflect a continuing fall in Scotland's share of the population. Currently, whenever public spending in Great Britain rises by $£ 100$, Scotland receives just under $£ 9$. Of course, these changes have not altered the aim of bringing per capita spending in Scotland and Wales closer to that in England. 
In practice, some public spending has always 'by-passed' the formula, but most public spending to Scotland has been determined on this basis. So Scotland's public spending per head has fallen in relation to England's, although it is still much higher as noted earlier. The rate at which the gap has fallen is lower than originally anticipated. This is because spending has risen more slowly than anticipated - in nominal terms - because inflation has been lower.

So there is some call for the formula to be scrapped. In 2001, the deputy prime minister John Prescott, suggested that it was time to 'bite the bullet' and reform the system (BBC, 2001), but fearing protests from Scotland, the government announced that the formula would remain. In Scotland, the Scottish National Party objects to the current 'Barnett squeeze', by which it means that when public spending in England rises by $1 \%$, it rises by around $0.8 \%$ in Scotland.

Perhaps the last word should lie with Barnett himself. He argued in 1997 that the present formula should be replaced with a Barnett formula Mark II that was based on spending needs (quoted in Twigger, 1998, 17). As there seems no sound basis for allocating expenditures except in relation to needs, the present paper helps to provide valuable insights into the relative needs of England and Scotland, and thus how they might fare with a Barnett Mark II.

\section{Using the English needs formulae to assess spending needs in Scotland}

The ODPM's estimates of spending needs by English LAs are called Formula Spending Shares (FSSs), while the SE's estimates of spending needs by Scottish LAs are called Grant Aided Expenditures (GAEs). Both the ODPM and the SE give each LA absolute figures for spending needs, but they stress that their methods reveal only relative needs, not absolute needs (ODPM, 2002, paragraph 10; Scottish Parliament, 2002). As our aim is only to estimate relative needs between the two countries, this limitation is not important.

The ODPM divides LA services into six blocks: education; personal social services; police; fire services; highway maintenance; and environmental, protective and cultural services (EPCS). In King et al (2004) we estimated the FSS for education which each Scottish LA would have if the FSS approach was used there. We chose education because it accounts for the largest share of LA spending. We found that, on average, Scotland's FSS per pupil would be just 3\% higher than in England. Under FSS, Scotland would gain compared with England because it has a relatively sparse population, but it would also lose because it has relatively fewer ethnic minority children, and it has lower costs for LA services, chiefly wages.

More recently, (King et al, 2006), we looked at the second largest component of LA spending, personal social services. Here, we find that the FSS approach puts Scotland's per capita needs 15\% above England's. Under FSS, Scotland would gain compared with England by having relatively more children in flats and in one-adult homes, and by having more adults in public sector flats and on social security benefits; but these gains would be partly offset by Scotland having relatively fewer people born outside the UK, fewer in densely populated areas, fewer aged over 75, and lower costs for LA services.

Given those contrasting results, the present paper looks at three groups of environmental services EPCS, highway maintenance and fire services, which in aggregate account for $24 \%$ of LA needs. Between them, our three papers cover 93\% of LA spending on services. 


\section{The context in which the needs assessment formulae are used}

The ODPM and SE calculate FSS and GAE figures for each LA in order to calculate the amount of general grant that they will pay to each LA. In effect, the total FSS or GAE figure for each LA is taken as an estimate of its need to spend, net of any specific grants which it receives. Some of this spending need will be covered by its share of the revenue from the uniform business rate. The general grant paid to it covers all the rest, except for the revenue which it would raise from the council tax if it set this at a rate suggested by the ODPM or SE.

In this paper, we first estimate what each Scottish LA's FSS per head for EPCS, highway maintenance and fire services would be if the FSS approach was used in Scotland. Then, for each service, we find the total FSS per head for Scotland, and compare this with the total FSS per head in England, which is assessed and published by the ODPM using FSSs. Thus we can see if the FSS approach suggests that Scotland has higher per capita needs than England.

We also want to compare the Scottish and English formulae. Unfortunately, we cannot use the FSS and GAE figures for Scottish LAs to make sharp comparisons of the two formulae's views about absolute needs. This is because Scottish LAs operate in a framework laid down by Holyrood while English LAs operate in a framework laid down by Westminster: these frameworks differ in policy details and in the use of specific grants. So if one formula generally gives higher estimates than the other, this might not mean that it is more generous; it might simply reflect the fact that it is tailored to a different framework. Moreover, we have already noted that the formulae do not claim to indicate absolute needs anyway, but rather claim to indicate relative needs. Fortunately, we can compare how they compare relative needs, by seeing if they agree which LAs have the highest and lowest relative needs.

\section{An overview of the FSS and GAE approaches to PSS}

The reason that England's FSS approach differs from Scotland's GAE approach is that, over many years, the former has been evolved by the Westminster government and the latter by the Scottish Office and, more recently, the SE. The FSS system estimates each LA's FSS for EPCS, highway maintenance and fire services by referring to a number of indicators. Table 1 shows the main indicators. The FSS formulae are discussed in detail in Sections VI to VIII.

Table 1 The FSS factors for three groups of environmental services, England, 2004-05

\begin{tabular}{|l|l|l|}
\hline EPCS & Highway maintenance & Fire services \\
\hline LA costs, chiefly labour & LA costs, chiefly labour & LA costs, chiefly labour \\
\hline Population & Daytime population & Population \\
\hline People on specified benefits & Total road length & People on specified benefits \\
\hline Commuters and day visitors & Road length in built-up areas & No. of non-detached homes \\
\hline People not born in UK & Traffic flow & No. of homes built 1919-44 \\
\hline Sparsely populated areas & Winter maintenance & Household composition \\
\hline Densely populated areas & & No. of rented homes \\
\hline & & Primary school absences \\
\hline & & High risk properties \\
\hline & & Coastline length \\
\hline
\end{tabular}

Source: ODPM (2004a). 
GAEs use rather different indicators from FSSs (see SE, 2000, Tables A-F). GAEs use more indicators for EPCS, because the SE divides EPCS into many separate services, each with its own indicators: Table 2 shows the main indicators in order of importance. For highway maintenance, GAEs estimate needs chiefly by using the length of lanes in LA roads (with a double weight for principal lanes), the length of urban lanes, and the number of private and light goods vehicles per unweighted kilometre; there is also an allowance for winter maintenance. For fire services, GAEs estimate needs chiefly by allowing for the costs of meeting standard response times in urban areas, on types and density of property, and spending on unfunded fire pensions. In addition to all these factors, GAEs make an island allowance for Eilean Siar, Orkney, Shetland and some other LAs.

\section{Table 2 The main indicators for GAE for EPCS, Scotland}

Adjusted population (residents, tourists \& commuters)

Dwellings and non-domestic rateable subjects

People outwith settlements of 10,000+ people

Housing Benefit and Council Tax caseload

People outwith settlements of $1,000+$ people

Burial ground hectares

Distance of people outwith settlements of 7,000+ to the nearest such settlements

Deprived districts (ones with much overcrowding, high unemployment, much permanent

sickness, or many 1-parent families or large households)

Building control warrants

Cremations and interments per hectare

Source: SE (2000, Tables A-F).

\section{The FSS formulae for EPCS and their application to Scotland}

This section applies the FSS formulae used for EPCS in 2004-05 to each Scottish LA and, in turn, to Scotland as a whole. ${ }^{3}$ These formulae are detailed by the ODPM (2004a, 32-36 and 79-81). For comparison purposes, our tables also show the FSS for England as a whole and for six individual English LAs (using data from ODPM 2004a, 2004b and 2004c). We chose these six LAs for reasons concerning their FSSs per head for EPCS, as follows:

- The City of Westminster, which has the highest FSS per head in England (aside from the City of London, whose small population makes it a questionable comparator).

- Liverpool, which has the highest English FSS per head outside London (aside from the Isles of Scilly, whose small population makes them a questionable comparator).

- Leicester, which has the highest FSS per head of any English unitary authority.

- Stockport, which has the lowest FSS per head of any metropolitan district.

- Bromley, which has the lowest FSS per head of any London borough.

- Wokingham, which has the lowest FSS per head of any English unitary authority.

The basic amount for EPCS, and fixed costs

The FSS formulae begin by allowing each LA a basic amount of $£ 121.04$ for each resident in 2002. Appendix 1 gives our source for population, and Table 3 shows this basic sum for each LA. The ODPM also allow each LA a sum of $£ 300,000$ to cover its fixed costs. Table 3 shows that, in per capita terms, this sum varies appreciably between LAs.

[Table 3 here] 


\section{Population density and sparsity}

The ODPM then make an allowance for density, to help LAs where a large percentage of the population live in densely populated areas. This problem is measured by a density index whose nature and sources are explained in Appendix 1. The ODPM allow £7.02 per head for each point that an authority secures on this index. Table 3 shows the per capita sums. Note that if two LAs had the same total population and the same total area, they need not have the same density index, for if $90 \%$ of the population in one LA was crammed into a small area, whilst the population in the other was widely distributed, then the former would have a higher index. Thus Wokingham has a lower density index than, say, Angus, because homes in Wokingham are less concentrated in settlements. Westminster gains because it has densely populated tall buildings that alternate with sparsely populated park areas.

The ODPM also make a sparsity allowance. They allow £34.91 for everyone who lives in a census enumeration district with from 0.25 to four residents per hectare, and $£ 68.91$ for everyone in sparser areas. Appendix 1 gives our sources. Table 3 gives the per capita sums.

Services for commuters and day visitors

The ODPM then make two allowances, noted below, for the fact that LAs provides some services for non-residents. Appendix 1 gives our sources. Table 3 gives the per capita sums.

- Net in-commuters. Suppose an LA has 100 more in-commuters than out-commuters each day. Then the FSS allows $£ 60.70$ over the year for each net in-commuter, that is $£ 6,070$ in all. But if the LA has more out-commuters than in-commuters, no negative allowance is made. Table 3 shows that the Scottish allowance per head slightly exceeds the English one; this is because England has many large towns close together, so many have very little net in-commuting. For example, Croydon has a population almost the same as Aberdeen and Dundee combined, but it has no net in-commuting.

- Day visitors. Suppose that an LA has on average of 100 visitors each day. Then the FSS allows $£ 76.25$ over the year for each of them, that is $£ 7,625$ in all.

\section{Deprivation and EPCS needs}

The ODPM then make several allowances for higher spending in deprived areas. We explain below how it allows for deprivation. Appendix 1 gives our sources for the various factors, and Table 4 shows the resulting per capita sums.

- $£ 201.50$ is allowed for everyone receiving incapacity benefit (IB) or severe disablement allowance (SDA).

- $\quad £ 303.25$ is allowed for everyone claiming income support (IS) or income based jobseeker's allowance (IBJSA).

- $\quad £ 129.67$ is allowed for all the elderly on IS or IBJSA (that is people aged 60 or more).

- $\quad £ 344.30$ is allowed for everyone claiming unemployment related benefits - currently jobseeker's allowance and national insurance credits.

- $\quad £ 65.84$ is allowed for each resident whose country of birth was not the UK, the Irish Republic, the European Community, the Old Commonwealth or the USA.

[Table 4 here] 
FSS also allows for area cost adjustments (ACAs) to reflect the varying cots of providing LA services across England (ODPM 2004a, 81). In high cost LAs, the ODPM raise the FSS sums found so far by applying ACAs. These range from $50 \%$ in the Isles of Scilly, $44.20 \%$ in the City of London, 23.29\% in the rest of inner London, to $0.96 \%$ in Merseyside, and $0 \%$ for LAs which do not receive them. We compared wage levels (from Table A21 of NES 2000, 2001 and 2002) over 2000-02 in Scottish LAs with those in English LAs that get ACAs, and we found that only Aberdeenshire, Edinburgh and Glasgow would be likely to get ACAs; Table 4 shows our estimated per capita sums for these LAs and the other Scottish LAs.

The generous ACAs for London boroughs are much offset by an ad hoc downward London adjustment. Table 4 shows the net per capita effect of ACAs minus this adjustment for England and for Westminster. Despite the offset, Westminster still gains $£ 70.45$ per head.

\section{The total FSS for EPCS}

In essence, all the components of Tables 3 and 4 can be summed to get the total FSS per head in each LA. However, the ODPM make some small scaling adjustments to ensure that the total FSS for EPCS in England equals a pre-determined figure called a control total. We made two identical adjustments for Scotland. Because of scaling, the total FSS per head figures shown in Table 4 differ by up to $£ 0.05$ from the sum of the various FSS components.

Scotland's average FSS per head is $£ 238.09$, which is $£ 14.37$ or $6.4 \%$ above England's figure of £223.71. The main reasons for Scotland's higher figure are its greater problems with both density and sparsity, which add $£ 8.23$, and its greater numbers of people on the various social security benefits, which add £13.07. However, England has more people born outside the UK, and it gets more ACAs. Although Scotland as a whole does better than England, the needs of its most needy LA, Glasgow, are $41.0 \%$ below those of Westminster, while the needs of its least needy LA, East Dunbartonshire, are only $4.7 \%$ above those of Wokingham.

\section{The FSS formulae for highway maintenance and their application to Scotland}

This section applies the FSS formulae used for highway maintenance in 2004-05 to each Scottish LA and, in turn, to Scotland as a whole. These formulae are detailed by the ODPM (2004a, 31 and 76-78). For comparison purposes, our tables also show the FSS for England as a whole and for six individual English LAs (using data from ODPM 2004a, 2004b and 2004c). We chose four of these six English LAs for reasons concerning their per capita FSSs for highway maintenance, and two because they are adjacent to Scotland, as explained below:

- The City of Westminster, which has the highest FSS per head in England.

- North Yorkshire, which has the highest FSS per head of the largely rural English LAs.

- Liverpool, which has the highest FSS per head of England's coastal cities.

- Northumberland, which is adjacent to Scotland.

- Cumbria, which is also adjacent to Scotland.

- Isle of Wight, which has the lowest FSS per head of the largely rural English LAs.

Before estimating an LA's FSS for highway maintenance, the ODPM divide the roads which it maintains into principal built-up roads, principal non built-up roads, other built-up roads, 
and other non-built up roads. A principal road is an A road (other than those that are trunk roads handled by central government). A built-up road is one with a speed limit of $40 \mathrm{mph}$ or less. Appendix 2 gives our source for road lengths. Table 5 shows each LA's total per head.

\section{Weighted road lengths}

The FSS formulae begin by allowing $£ 411.62$ for each kilometre of weighted road length. Weighted road lengths give a weight of 2 to built-up roads and of 1 to other roads. Table 5 shows the per capita sums for each LA (Appendix 2 gives our source for population figures).

[Table 5 here]

\section{Traffic flow}

The ODPM also allow that maintenance costs depend on traffic flow. For each LA, the ODPM estimate a traffic flow index as follows: they add the total usage of its principal roads, in million vehicle kilometres, to 100 times the usage of its principal roads by heavy goods vehicles (including buses and coaches) in millions of vehicle kilometres, and then divide this sum by the total length of principal roads in the LA. The traffic flow payment is this index times $£ 77.12$ for each kilometre of weighted road length. Appendix 2 gives our sources, and Table 5 shows the per capita sums for each LA. The average per capita sum for Scotland is similar to the average for England: for although each English kilometre is used by about twice as many vehicles, England has only about half as many weighted road kilometres per head.

\section{Daytime population}

The ODPM also allow that the costs of maintaining a kilometre of roads depend on population, specifically an LA's so-called daytime population. This comprises:

- the LA's resident population;

- plus the number of commuters who come into the LA to work minus the number who leave the area to work - note that this element is ignored if there is a net outflow;

- plus the number of domestic and foreign visitors in the LA over an average night;

- plus the number of day visitors to the LA who visit it during an average day. Appendix 1 gives our sources. The ODPM divide the daytime population by the total unweighted road length to get the daytime population per kilometre. This figure is multiplied by $£ 5.48$, and then by the total weighted road length, to get the FSS allowance for daytime population. Table 5 shows the per capita sums (in terms of the resident population).

\section{Winter maintenance}

The ODPM then allow that some LAs have to do more winter maintenance than others, in terms of clearing snow and gritting. To allow for this, the ODPM estimate for each LA the average number of days per year with snow lying at 0900 hours, and the average number of days per year when gritting is needed. For each snow day they allow $£ 3.15$ per weighted kilometre of roads, and for each gritting day they allow $£ 7.10$ per weighted kilometre of roads. Unfortunately, there are no data are available on snow days and gritting days in Scotland that are directly comparable to the ODPM estimates for England, but we made some estimates, as explained in Appendix 2. Table 5 shows the resulting per capita sums. 
Finally, FSS uses ACAs to help LAs with relatively high costs. It raises the FSS figures found so far by applying ACAs that range from $44.20 \%$ in the City of London and $23.29 \%$ in Inner London boroughs to $0.96 \%$ in Merseyside and 0\% for LAs which do not receive them. As noted above, we found that only Aberdeenshire, Edinburgh and Glasgow would be likely to get ACAs; Table 5 shows our per capita estimates for them and the ODPM's English figures.

\section{The total FSS for highway maintenance}

In essence, all the components of Table 5 can be summed to get the total FSS per head in each LA. However, the ODPM make a slight scaling adjustment to ensure that the total FSS for highway maintenance in England equals a pre-determined control total. We scaled our Scottish figures by an identical proportion. Because of scaling, the total FSS per head figures shown in Table 5 differ by $£ 0.01$ from the sum of the various FSS components.

Scotland's average FSS per head is $£ 43.72$, which is $£ 3.29$ or $8.1 \%$ above England's figure of $£ 40.43$. The main reasons for Scotland's higher figure are its greater weighted road length per head and its problems with winter maintenance. Indeed, Scotland's highest needs arise in Shetland and Orkney which suffer badly from both problems. In contrast, England gains more from the daytime population allowance and from higher ACAs, and its highest needs arise in Westminster, which suffers badly from both these problems.

\section{The FSS formulae for fire services and their application to Scotland}

Fire services are usually provided by fire authorities that cover several LAs and are run by boards appointed by those LAs. Scotland has eight fire authorities. This section applies the FSS formulae for fire services in 2004-05 to each Scottish fire authority and hence to Scotland as a whole. These formulae are detailed by the ODPM (2004a, 29-30 and 73-75).

For comparison purposes, our tables also show the FSS for England as a whole and for five individual English fire authorities (using data from ODPM 2004a, 2004b and 2004c). We chose these five LAs for reasons concerning their per capita fire service needs, as follows:

- The Isles of Scilly which have by far the highest fire FSS per head.

- London which has a very high fire FSS per head.

- Cornwall which, like most Scottish authorities, has a lot of coast.

- The Isle of Wight which also has a lot of coast.

- Lincolnshire which has the lowest fire FSS per head of coastal authorities and, indeed, one of the lowest per capita FSSs of all fire authorities.

The reasons for our interest in coastal authorities will become clear below.

\section{The basic amount for fire services}

The FSS formulae begin by allowing each fire authority a basic amount of $£ 18.03$ for each resident in 2002. Appendix 3 gives our source on population, and Table 6 shows this basic sum for each Scottish fire authority and each English comparator. This basic amount accounts for about half the total FSS in England but for rather less than half in Scotland. 
[Table 6 here]

Deprivation and fire service needs

Each authority is also allowed a 'fire deprivation top-up'. The amount of top-up allowed to any given authority depends on the six deprivation indicators explained below. Appendix 3 gives the relevant sources, and Table 6 shows the effects of each indicator on FSS per head.

- The proportion of children dependent on people claiming IS or IBJSA. Call this A. The per capita allowance is $£ 0.50[(\mathrm{~A}-0.1930) / 0.0679+3]$.

- The proportion of households whose property is not a detached house or a detached bungalow. Call this B. The per capita allowance is $£ 0.50[(\mathrm{~B}-0.7819) / 0.1077+2]$.

- The proportion of households in properties built between 1919 and 1944, when building regulations were not as tight as they later became. Call this proportion $\mathrm{C}$. The per capita allowance is $£ 0.50[(C-0.2006) / 0.0698+2]$. We were unable to obtain the relevant proportions for individual Scottish fire authorities, so we assumed that each had the Scottish average. This assumption does not affect our estimate of Scotland's total fire FSS, and it has little impact on the estimates for individual authorities because this indicator accounts for under 1.5\% of Scotland's total fire FSS.

- The proportion of households whose composition is not a childless couple. Call this D. The per capita allowance is $£ 0.50[(\mathrm{D}-0.7277) / 0.0416+2]$.

- The proportion of people in rented accommodation. Call this E. The per capita allowance is $£ 0.50[(\mathrm{E}-0.2671) / 0.0635+2]$.

- The average number of half-day absences of primary age pupils. Call this $\mathrm{F}$. The per capita allowance is $£ 0.50[(\mathrm{~F}-23.0733) / 1.8897+3]$.

The complex relationships between the indicator values and the sums allowed for FSS mean that the sums are not proportional to the indicators. Indeed, the sums allowed are sometimes negative: for example, this applies with primary absences to three Scottish fire authorities.

Fire safety

The ODPM allow three further top-ups relating to different aspects of fire safety, as explained below. Appendix 3 gives the relevant sources and Table 7 shows the per capita top-ups.

- A 'fire-risk' top-up. This allows $£ 1,216.27$ for each hectare in the authority which is classified as 'A risk' in terms of fire cover. Scotland has relatively few such hectares.

- A 'fire safety enforcement' top-up. This allows $£ 220.40$ for each certificatable premise and for each plan examined. Scotland has relatively few such premises.

- A 'community fire safety' top-up. This allows $£ 8.45$ for each pupil aged 5-10 and $£ 1.69$ for each resident with a 'greater need for fire safety education' (ODPM 2004a, 75). The ODPM estimate the number of these residents using unpublished data and methods, so we could not make comparable estimates for Scotland. So we simply assumed that in each Scottish fire authority the number of these residents was $26 \%$ of the population, which is the ODPM average for England. This procedure is not very satisfactory, but this factor accounts for under $1 \%$ of the total fire service FSS, so any inaccuracies in our estimates should have almost no impact on our results.

[Table 7 here] 


\section{Coastline}

The ODPM allow a coastline top-up of $£ 688$ per kilometre of coast. There are at least three factors that may cause relatively high costs in coastal fire authorities: (1) they are less able to get help from adjacent authorities when their own resources are stretched; (2) they may get calls concerning coastal flooding; and (3) they may get calls concerning coastal rescue.

The ODPM estimate coastline lengths 'generally using Ordnance Survey [OS] data' (2004a, 73, and 2004b), and give England a total coastline of 4,004 kilometres. However, the OS itself (2005) give 10,077 kilometres including islands and 8,982 kilometres excluding islands. The ODPM could not tell us how they had derived their much shorter estimates from OS data. Their only suggestion was that their estimates might relate to low tide whereas the OS data is for high tide. However, it is unlikely that the English coast halves in length at low tide. Also, the OS tell us that they have no low tide data which they could have supplied to the ODPM.

The ODPM probably omitted some islands and used smoothed coastline elsewhere. Smoothed coastlines might be appropriate for factor (1) noted above, but less appropriate for factors (2) and (3). However, as the ODPM cannot tell us if or how the smoothing was done, we cannot apply similar smoothing to fire authority coast lengths in Scotland.

The OS (2005) give the Scottish coastline as 6,718 kilometres excluding islands and 18,588 kilometres including islands. We began with the latter because most large Scottish islands are inhabited. The ODPM English coast is about $40 \%$ of the unsmoothed OS length including islands. Applying this percentage to Scotland gives a figure of 7,386 kilometres. However, the SE (2001a, Annex 1) gives a smoothed coastline length for Scotland of 9,911 kilometres. So we chiefly used an intermediate figure of 8,500 kilometres, but we also report below the effects of 7,000 and 10,000 kilometres, which seem plausible limits.

We derived initial coastline lengths for the Scottish fire authorities from Scottish Office data (1998, Table 2.1) which actually give Scotland a total coastline of 13,115 kilometres. We then scaled all these figures to get a total of 8,500 kilometres. Table 7 shows the per capita top-ups at $£ 688$ per kilometre. In practice, it is unlikely that smoothing would shrink each authority's coast by the same proportion, so our scaled estimates for individual authorities are very approximate; but using a uniform scaling does not affect the total FSS for Scotland

\section{Area cost adjustments for fire services}

The ODPM also use ACAs to help authorities with relatively high costs. In these, the ODPM raise the FSS figures found so far by applying ACAs that range from $18.19 \%$ in London to $1.04 \%$ in Merseyside and $0 \%$ for authorities which do not receive them. As noted above, we found that only Aberdeenshire, Edinburgh and Glasgow would be likely to get ACAs; Table 7 shows our estimated per capita ACAs for them and also the ODPM's English figures.

\section{Fire pensions}

The final factor allowed in FSS is fire pensions. Effectively, the ODPM (2004a, pp.30 and 75) allow each fire authority an amount equal to its projected 2004-05 expenditure on pensions, which is in fact $16 \%$ of the FSS for fire services. We allowed each Scottish fire 
authority the amount allowed for pensions in the 2004-05 GAE of its constituent LAs (from SE, 2003d). This averages a very comparable $17.3 \%$ of the total GAE for fire services.

\section{The final FSS for fire services}

In essence, all the components of Tables 6 and 7 can be summed to get the total FSS per head in each authority. However, the ODPM make some slight scaling adjustments to ensure that the total FSS for fire services for England equals a pre-determined control total, so we scaled our Scottish figures by an identical proportion. Because of scaling, the total FSS per head figures shown in Table 7 differ by up to $£ 0.41$ from the sums of the various FSS components.

Taking Scotland's coastline as 8,500 kilometres gives it an average FSS per head of $£ 48.40$, which is $£ 11.12$ or $29.8 \%$ above England's figure of $£ 37.28$. Scotland gains chiefly because its greater coast per head gives it $£ 11.01$ per head more, although it also gains slightly on several other factors. However, its overall gain is reduced because it has fewer primary school absences and lower ACAs. Scotland's highest FSS per head by far arises in Highland and Islands, on account of its coast; even so, the FSS per head here is way below that for the Isles of Scilly. If we use the upper and lower limits for Scotland's coast of 7,000 and 10,000 kilometres, then we put its FSS between 24.3\% and 35.3\% above England's.

\section{Scotland and England compared}

The main aim of this paper is to compare how much Scottish LAs would be found to need to spend on the FSS formulae with the amounts that English LAs are found to need to spend. However, it is also interesting to compare what would happen in Scotland under FSS with what actually happens under Scotland's GAE system. This section takes each service in turn.

\section{EPCS}

Table 8 repeats the FSS needs per head for EPCS from Table 4. It also gives the per capita 2004-05 needs for these services as assessed on GAE (from SE, 2003b). Here, we take the GAE for EPCS to cover all LA services except education, personal social services, police, fire services, and the transport elements of the SE's roads and transport block.

Scotland's average GAE of $£ 233.00$ is $2.14 \%$ below its FSS of $£ 238.09$. In fact, England’s system is even more generous, for in 2004-05, English LAs received specific grants for these services that would take their spending 11.54\% above their FSSs (ODPM, 2004d, Key Table 1). In contrast, Scottish LAs received virtually no specific grants for these services (SE, 2003a). If Scotland's needs on the English approach are raised by $11.54 \%$ above its FSS, then GAE assesses Scotland's needs at $12.26 \%$ less than FSS. However, as noted in Section IV, sharp comparisons of absolute need under FSS and GAE are not possible, because FSS and GAE relate to the different frameworks in which Scottish and English LAs operate.

However, we can compare how FSS and GAE assess relative need, and this is shown in the next two columns in Table 8. One of these columns shows each Scottish LA's FSS per head relative to the Scottish average FSS per head, and one shows each Scottish LA's GAE per head to the Scottish relative to the Scottish average GAE per head. Urban LAs like Edinburgh and Glasgow fare much better under FSS: Edinburgh gets 14\% above average with FSS and $4 \%$ below with GAE, while Glasgow gets $42 \%$ above average with FSS and 
only 19\% above with GAE. In contrast, some rural LAs like Argyll and Bute and Highland fare much better with GAE. But the most striking differences arise with the island LAs: most notably, Shetland gets $10 \%$ below average with FSS and $213 \%$ above average with GAE.

These differences might reflect different views about needs in Westminster and Holyrood. If, instead, they have similar views, then it seems that at least one of them assesses relative EPCS needs poorly. Maybe GAE underestimate needs in urban LAs, or FSS underestimates needs in rural LAs. If FSS underestimates rural needs, then it may underestimate Scotland's needs relative to England's; for Table 3 shows that Scotland receives about twice as much per head as England for people in sparse areas, which implies that Scotland is relatively rural. In turn, Scotland's needs may exceed England's by more than the $6.4 \%$ indicated in Section VI.

[Table 8 here]

\section{Highway maintenance}

Table 8 repeats the FSS needs per head for highway maintenance from Table 5. It also gives the per capita 2004-05 needs for roads as assessed on GAE (from SE, 2003b); these figures are based on the roads part of the SE's roads and transport block. Scotland's average GAE of $£ 54.94$ is $25.6 \%$ above its FSS of $£ 43.72$. England had no specific grants for highway maintenance in 2004-05 (ODPM, 2004d, Key Table 1) so this gap does seem to reflect a much more generous Scottish approach. But, as noted earlier, differences in the frameworks under which Scottish and English LAs operate mean that this gap may be misleading.

To compare how FSS and GAE assess relative need, Table 8 has one column showing each Scottish LA's FSS per head relative to the Scottish average FSS per head, and one showing each Scottish LA's GAE per head to the Scottish relative to the Scottish average GAE per head. As with EPCS, the urban LAs of Edinburgh and Glasgow do better with FSS than GAE, with Edinburgh getting 10\% above average on FSS and 31\% below on GAE; Aberdeen is in an almost identical position. And again, the rural and island LAs do better with GAE. For example Argyll and Bute get 2\% above average on FSS and 100\% more on GAE, and Eilean Siar gets $28 \%$ above average on FSS but 334\% more on GAE.

As with EPCS, these differences might reflect different views about needs in Westminster and Holyrood. If, instead, they hold similar views, then it seems that at least one of them assesses relative highway maintenance needs poorly. Maybe GAE underestimates needs in urban LAs, or FSS underestimates needs in rural LAs. If FSS does underestimate rural needs, then Scotland's needs may exceed England's by more than the $8.1 \%$ indicated in Section VII; for, as noted above, the data on population sparsity suggest that Scotland is relatively rural.

\section{Fire services}

Table 9 repeats the FSS needs per head for fire services from Table 7. It also gives the per capita 2004-05 needs for fire services as assessed on GAE (from SE, 2003b). At $£ 49.13$ per head, GAE seems a shade more generous than FSS at £48.40; and in 2004-05 England had no specific grants for fire services that would take their assessed needs above FSS (ODPM, 2004d, Key Table 1). If Scotland's coast should actually be taken as 7,000 kilometres instead 
of 8,500, then its FSS per head falls to $£ 46.35$ and hence further below GAE; but if it should be taken as 10,000 kilometres, then its FSS per head rises above GAE to $£ 50.45$. But note, once again, that differences in the total FSS and the total GAE may simply result for the fact that they relate to the different frameworks in which Scottish and English LAs operate.

[Table 9 here]

To compare how FSS and GAE assess relative need, the third and fourth columns in Table 9 respectively show each Scottish fire authority's FSS per head relative to the Scottish average FSS per head, and each Scottish fire authority's GAE per head to the Scottish relative to the Scottish average GAE per head. There is a huge difference for Highland and Islands: this authority would get $243 \%$ more than the average under FSS, chiefly because of its long coast, but it gets only 1\% more under GAE. Perhaps the English coastline top-up is over generous.

Given the huge difference with Highlands and Islands, we produced two more sets of relativities that omit them, as shown in the final two columns of Table 9. There are still some big differences. For example Tayside gets $2 \%$ above average with FSS but $20 \%$ above with GAE. So it still seems that at least one approach must measure relative needs poorly, unless Holyrood and Westminster have very different ideas on what is meant by spending needs.

\section{Conclusions}

\section{Comparison of per capita spending needs in Scotland and England}

The main aim of this paper is to shed light on the extent to which Scotland has higher per capita spending needs than England for public services. It has done so by applying the English FSS formula for assessing LA needs to Scottish LAs. FSS indicates that in 2004-05 Scotland needed 6.4\% more per capita for EPCS, 8.1\% more for highway maintenance, and between $24.3 \%$ and $35.3 \%$ more for fire services.

Elsewhere, we have applied FSS to Scotland for two other groups of LA services. In King et al 2006, we find that applying to Scotland the FSS formulae for LA spending needs on personal social services in 2004-05 indicated that Scotland's per capita needs were about 15\% above England's. Earlier, in King et al 2004, we found that applying to Scotland the FSS formulae for LA spending needs on education in 2003-04 indicated that Scotland's needs per pupil were about 3\% above England's; however, because Scotland has slightly fewer pupils in relation to its overall population, its FSS per head is actually about $1 \%$ below England's.

Taking all these results together, and weighting the results of each group of services by its contribution to total FSS, our research indicates that Scotland's per capita needs for all LA services (except police) is between 5.5\% and 6\% above England's, the exact figure depending on the relative needs assumed for fire services. A figure between $5.5 \%$ and $6 \%$ is, of course, way below the $25 \%$ by which per capita spending on public services in Scotland exceeds England's. It is true that the LA services we have explored omit almost half public services, but for the true overall figure to be $25 \%$, Scotland's needs on the others, such as health, would have to exceed England's by a very improbable amount of nearly 50\%. 
We must stress that the comparisons of need in Scotland and England just noted are only as robust as FSS is itself at indicating relative need. It was to throw some light on this that we contrasted the estimates of relative needs for Scottish LAs that FSS would yield if it were used in Scotland with the estimates of relative need that GAE does yield.

With both EPCS and highway maintenance, we saw that FSS may underestimate needs in rural areas. For example, under FSS, Highland would be allowed 13\% less than the Scottish average for EPCS and 28\% more for highway maintenance; but under GAE it is allowed 10\% more than the average for EPCS and 113\% more for roads. Also, FSS may overestimate needs in urban areas. For example, under FSS, Glasgow would be allowed $42 \%$ more than the Scottish average for EPCS and 9\% less for highway maintenance; but under GAE it is allowed 19\% more than the average for EPCS and 44\% less for roads. If FSS does underestimate needs in rural areas, and overestimate them in urban areas, then it will tend to underestimate needs in Scotland as a whole, so Scotland's relative needs may be higher than FSS suggests. However, it is possible that FSS measures relative needs for these services well, while GAE underestimates needs in urban areas and overestimate them in rural areas.

With fire services, we found that, compared with GAE, FSS was relatively favourable to coastal authorities, and, in turn, less favourable to others. If FSS overestimates needs in coastal areas, then it will tend to overestimate needs in Scotland as a whole, so Scotland's relative needs may be lower than FSS suggests. However, it is possible that FSS measures relative needs for fire services well, while GAE underestimates needs in coastal areas and overestimate them in inland areas.

Our paper on personal social services provided by LAs (King et al 2006) reveals a similar tendency for FSS to favour urban areas. For example, compared with the Scottish average, Glasgow is allowed 21\% more needs per head under GAE while Perth and Kinross is allowed 5\% above average, but Glasgow would be allowed 56\% above average with FSS while Perth and Kinross would be allowed $17 \%$ below average.

In contrast, our paper on local education services (King et al 2004) did not reveal any clear tendency for FSS to favour urban areas. For example, Glasgow receives 8.1\% above average under GAE, and it would do little better, just 9.6\% more, with FSS. And while Edinburgh receives 3.6\% more than the Scottish average under GAE, it would actually receive $4.3 \%$ less under FSS. Of course, the difference in Edinburgh's treatment indicates that it can now spend far more on education than would be allowed under FSS.

\section{General conclusions}

In addition to the above results, five more general conclusions can be drawn. First, we have argued that the differences in the way in which FSS and GAE assess relative need may indicate either that at least one of them is seriously flawed; possibly both are flawed. Such flaws can be taken to reflect the difficulty of devising sound objective estimates of needs. Because it is hard to assess needs, there is a case for having a system of local government finance that minimises the impact of errors. At present, local taxes cover only a small percentage of local spending, so errors in needs assessment mean that LAs with underestimated needs must either accept relatively poor services or have very high local tax rates compared with other LAs. If the current local government funding reviews in each 
country led to local taxes raising a larger share of local revenue, then the proportionate differences in local tax rates needed to offset poor needs assessments would be lower.

Secondly, the fact that FSS or GAE, or perhaps both, may be flawed, forms a strong case for reviewing them both. These reviews could examine whether FSS favours urban areas and whether GAE favours rural areas. The present paper does not seek to see which formula is 'better'. However, those who devised GAE might wonder, for example, why FSS does not split EPCS into separate services with their own indicators, why FSS gives generous allowance for road maintenance to LAs with large day-time population inflows irrespective of whether or not the visitors arrive by road, and why FSS gives such generous fire service allowances to coastal areas. Conversely, those who devised FSS might wonder, for example, why GAE offers no allowance in EPCS to LAs with dense populations, and why GAE does not allow for varying costs, especially wage costs, between LAs; but here it may be noted that there is a case for ignoring varying costs, and thus ensuring that high cost areas have relatively high tax rates or relatively low service levels, for this will encourage some migration from high cost areas to low cost areas (see, for example, King, 1984, 145).

Thirdly, in any reviews, there must be a case for Holyrood and Westminster seeing what they can learn from each other about needs assessment. In turn, there may seem to be a case for using this pooled wisdom to devise needs assessment formulae that could be applied in both England and Scotland. However, caution should be exercised here. One reason for caution is that Westminster and Holyrood set their LAs in different frameworks, so wholly identical formulae would be inappropriate; and these differences may grow the longer Holyrood has to flex its powers. Another reason for caution is that a major argument for devolution is that it allows different areas to try out different ideas, so that comparisons can be made and lessons drawn. Our comparisons of FSS and GAE point strongly to the need to review the formulae, but such a conclusion could not be made if each country used the same formulae.

Fourthly, because FSS may be flawed, its indication that Scotland's per capita needs are around 6\% above England's may be a significant understatement. Even so, many people will doubt whether Scotland's needs exceed England's to the same extent that its per capita public spending exceeds England's. So there may well be a case for replacing the current Barnett formula by a Barnett Mark II formula which assesses the needs for public spending as a whole across the two countries. There would certainly be a case for doing this if, in future, under a scheme of significant financial devolution, the Scottish Executive raised most of its revenue from taxes and received Westminster funds only to cover higher needs.

Finally, while the case for devising a Barnett Mark II formula seems strong, Barnett Mark II will be very hard to devise. It will be harder than assessing LA spending needs, because it will have to cover devolved central government services as well as LA services. Also, for political reasons, it will surely have to be accepted as fair in both Scotland and England; yet there are several results in this paper which suggest that Scotland and England may hold very different views about needs, so satisfying both countries may prove problematic. However, we hope that the work in this paper and our two others, along with the many data sources that we have identified, will help anyone who does try to devise such a formula.

\section{Appendix 1 - data for FSS for EPCS}

Note that for each factor, the data used by the ODPM are detailed in italics. 
Resident population, 2002. We obtained Scottish LA data from GROS (2002, Table 1).

Population density index, using the 1991 Census districts. The ODPM began with the number of residents per ha in each district. Each LA has hundreds of districts, but to see the process, suppose a LA had just two districts, $\mathrm{X}$ with 30,000 people and 100 ha and $\mathrm{Y}$ with 10,000 people and 100 ha. So X's density is 300 per ha and Y's 100 . The population per ha of each district is multiplied by its share of the total LA population, and the results added; so as $X$ has $3 / 4$ of the population and $Y$ has $1 / 4$, we get $3 / 4(300)$ plus $1 / 4(100)$ which is 250 . This number is then scaled in line with the change in the LA's population between 1991 and 2002, and then divided by 10 . If the LA's population rose by $4 \%$ over this period, then its index is $1.04(250) / 10$ or 26 . Unfortunately, data for 1991 districts is not published, so we used data for the hundreds of census output areas used in the 2001 Census (SCROL 2005, Table UV02) and scaled it in line with population changes by 2002 (from SCROL, Table UV04).

Proportions of the population in sparse areas with up to 0.25 people per ha and from 0.25 to 4 people per ha using the 1991 Census districts. As data for 1991 census districts is not published, we used census output areas in the 2001 Census (SCROL 2005, Table UV02).

Net in-commuters, using the 1991 Census. As Scottish LAs have been reorganised since 1991, we used the 2001 Census, and found the difference in each LA between the resident population and the daytime populations (SCROL 2005, Tables UV04 and UV38).

Average number of day visitors, using data available in 1993. The ODPM use a variety of sources, some unpublished. A key source is a survey which shows that in 1988-89 there were 1,484 million day visits in England and 110 million in Scotland, so Scotland's figure equals 7.41\% of England's; these figures are for all trips lasting three hours or more (Office of Population Censuses and Surveys 1991, 5-7). The ODPM also use data from the Census of Employment, and Office of Population Censuses and Surveys (1991, p.19) notes that on that Department's definition, which concerns return journeys of over 20 miles, there were 551 million day visits in England and 40 million in Scotland, so Scotland's figure equals 7.26\% of England's. In their FSS calculations, the ODPM (2004b, Table 1) use an England total of 887 million, somewhere between the 1,484 million and the 551 million just noted. We therefore assumed that Scotland had a total of 65 million: this is $7.33 \%$ of 887 million, and we used $7.33 \%$ as being about midway between $7.26 \%$ and $7.41 \%$. To allocate the 65 million between the Scottish LAs we began with Scotexchange (2003) which gives figures for leisure day visits in each of the 14 Tourist Board areas over a whole year, varyingly 2001 and 2002. Most tourist board areas cover more than one LA, and in these we split the figures in proportion to the 2002 populations of the relevant LAs. We then divided the figures by 365.

Claimants of IB or SDA, averaged over 1999 to 2001. We obtained 1999 and 2000 Scottish LA data from National Statistics (2005c) and 2001 data from DWP (2005d).

Claimants of IS or IBJSA, averaged over 2000 to 2002. For IS claimants, we used Scottish LA data for 2000, 2001 and 2002 from National Statistics (2005b) and DWP (2005a and 2005b). We were able to obtain data for IBJSA claimants only for 2001 (from DWP, 2005c): we raised these figures by $4.14 \%$ as the average number of claimants in Great Britain over 2000-02 was 4.14\% above the 2001 number (from National Statistics 2004, Table 10.6). 
Elderly people, aged 60 or more, who claim, or whose partner claims, IS or IBJSA, averaged over 2000 to 2002. For IS, we obtained Scottish LA data from the sources noted in the last paragraph. For IBJSA, DWP (2002, Table 5.2) says that 924,000 people claimed JSA in 2002 in Great Britain, with 70.4\% of them on IBJSA, that is 650,496. The same source also says that 9,000 people aged 60 or over claimed JSA in 2002 in Great Britain, and that 27.1\% of them were on IBJSA, that is 2,439 . So we assumed that 2,439/650,496, of all JSA beneficiaries are 60 or over. The same source also says (Table 4.3) that Scotland has as IBJSA beneficiaries 75,000 claimants plus 9,000 partners, that is 84,000 people. So we infer that in Scotland 2,439/650,496 of 84,000 - that is 315 - people are IBJSA claimants or partners of claimants aged 60 or more. We raised this number by $10.20 \%$ to 347 as National Statistics (2004, Table 10.6) showed that the average number of claimants in Great Britain over 2000-02 was $10.20 \%$ higher than the 2002 number. We split these 347 people by LA in proportion to the total claiming IBJSA in 2001 (from DWP 2005c Table).

Claimants of unemployment related benefits, averaged between 2000 and 2003. These benefits are currently jobseeker's allowance and national insurance credits. We obtained Scottish LA data for 2000, 2001, 2002 and 2003 from SE (2005b). The average figure for Scotland did not quite square with the Scottish average given by National Statistics (2004, Table 7.14) and nor did the average used by ODPM quite square with the English average given there. So we scaled our figures to ensure that the Scottish average differed from the National Statistics one by the same proportion as the English average.

Residents born outside the UK, the Republic of Ireland, the European community, the Old Commonwealth and the USA, using the 1991 Census. We obtained Scottish LA data from GROS (1993) Table 7.

\section{Appendix 2: Sources of data for highway maintenance}

Note that for each factor, the data used by the ODPM are detailed in italics.

Road lengths, 2003. We took Scottish LA 2001 data from Department for Transport (2004). We used 2001 data because later published data split roads between rural and urban, not built-up and non built-up as needed for FSS.

Resident population, 2002. We obtained Scottish LA data from GROS (2002, Table 1).

Traffic flow, using 2002 data. Damien de Niese at the Department for Transport gave us 2003 data for the use of Scottish LA principal roads by (a) all motor vehicles and (b) heavy goods vehicles, buses and coaches. The total for (a) was 12.0 billion vehicle $\mathrm{km}$. We scaled all the 2003 figures for (a) to get the total usage for 2002 of 11.7 billion vehicle $\mathrm{km}$ given in National Statistics (2003, Table 4.2). We scaled all the (b) figures in the same proportion.

Net in-commuters, using the 1991 Census. We give our sources and methods in Appendix 1.

Average number of nights stayed by domestic and foreign visitors. The ODPM use data from several sources for years up to 2002. We took data from Scotexchange (2003) for the numbers of domestic and foreign visitors staying in each of the 14 Scottish Tourist Board areas over a whole year, varyingly for 2001 and 2002. Most Board areas cover more than 
one LA, and there we split the figures in proportion to the 2002 populations of the LAs concerned.

Average number of day visitors, using data available in 1993. Our sources and methods were the same as those given in Appendix 1.

Number of days per year with snow lying at 0900, averaged over 1978 to 1990. The ODPM make estimates for English LAs using Meteorological Office data for weather stations, and they have not made estimates for Scottish LAs. However, the Meteorological Office (2005, map for 'Days of Snow Lying') gives a map showing estimates for the entire country of the average number of days with snow lying at 0900 averaged over 1971 to 2000 . We used this map to make our own estimates for each Scottish LA. We also made estimates for several English LAs to check that they were close to the ODPM's estimates (ODPM 2004b, Table 1).

Number of days per year when gritting is needed, averaged 1992-93 to 2001-02. As with snow lying days, the ODPM make estimates for English LAs using Meteorological Office data for weather stations, and they have not made estimates for Scottish LAs. So we studied the ODPM data for some north England LAs and found that there were between 31 and 46 more gritting days than snow days, with an average 38.9 more days; so we added 38.9 to our Scottish LA snow day estimates to form our gritting day estimates.

\section{Appendix 3 - data for fire services FSS.}

Note that for each factor, the data used by the ODPM are detailed in italics. Note too that we first estimated a FSS for each LA and added these as needed to get one for each fire authority.

Resident population, 2002. We obtained Scottish LA data from GROS (2002, Table 1).

The number of children dependent on IS or IBJSA claimants, averaged over 2000 to 2002, as a proportion of residents aged under 18 in 2002. For dependants of IS claimants, we used Scottish LA for 2000, 2001 and 2002 from National Statistics (2005b), and DWP (2005a and 2005b). We were able to obtain data Scottish LA data for dependants of IBJSA claimants only for 2001 (from DWP, 2005c): we raised these figures by $4.14 \%$ as the average number of claimants in Great Britain over 2000-02 was 4.14\% above the 2001 number (from National Statistics (2004, Table 10.6).

The proportion of households whose property is not a detached house or bungalow, averaged over 2000-01 to 2002-03. We found Scottish LA data on properties and detached properties in 2001 from SCROL (2005, Table UV56). For 2002 and 2003, we found the number of properties in each LA from SE(2005a, Household Projections Table 5a) and the percentage of detached properties in various small groups of LAs from SE (2002, Table 1, and 2003c, Table 4.10); for each group, we assumed that the same proportion applied to each LA.

The proportion of households whose property was built between 1919 and 1944, averaged over 2000-01 to 2002-03. The ODPM use LA data from a survey that covers England alone. All we could do was to estimate the proportion for Scotland as a whole, and assume that this applied in each authority. Chris Gosling at the SE informed us that 365,443 dwellings were completed in Scotland between 1920 and 1944; unfortunately, there is no figure for 1919. However, assuming that a few dwellings built between 1919 and 1944 have been demolished, 
365,443 seems a reasonable estimate of the number of dwellings from this period that survive. The average number of households over 2000-03 was 2,209,393 (from SE, 2005, Household Estimates and Household Projections Table 1). So we inferred that the proportion of dwellings built in this period was $365,443 / 2,209,393$, that is 0.1654 .

The proportion of households that do not contain a couple with no children, averaged over 2001 to 2003. We obtained Scottish LA data for 2001 from SCROL (2005, Table KS20) and a 2001 figure for England of 0.7330 (from National Statistics 2005a, Table KS20). The ODPM's estimate of the English average for 2001 to 2003 is 0.7225 (ODPM, 2004b). So we scaled the Scottish 2001 LA figures by 0.7225/0.7330 to estimate averages for 2001 to 2003.

The proportion of people living in rented accommodation, averaged over 1999-2000 to 200102. We obtained Scottish LA data for 1999-2000 and for 2001 (from SE 2001b, Table 2.1, and SCROL 2005, Table UV44) and used weighted averages of these.

The number of half-day absences, both authorised and unauthorised, for the average primary school pupil, averaged over 2000-01 to 2002-03. We used Scottish LA data for the number of half days absences and the number of pupils (from SE 2003a, Table 5a, and 2003b, Table for Primary Pupils). Primary schools in Scotland take children up to the age of 12, not 11 as in England, and 12 year olds may be absent more often than 5-11 year olds, so our Scottish figures may be a little too high; but we ignored this as they are well below the English figures.

'A' risk areas. We obtained hectare figures for Scottish fire authorities from Mr Jim Heatherill of HM Fire Services Inspectorate.

Fire safety enforcement. The ODPM allow for each premise with a certificate issued in 2002-03 under the 1971 Fire Precautions Act, or the 1967 Factories Act, or the 1963 Offices, Shops and Railways Act. They also allow for each premise with an exemption certificate, each premise subject to notices requiring work to be carried out, and each premise where applications for certificates had been carried forward to the following year. We estimated these totals from a document Fire Safety Statistics for 2002-03 by Brigade with Scottish Totals supplied by Mr Jim Heatherill of HM Fire Services Inspectorate.

Community fire safety: pupils aged 5-10 in 2001-02. For pupils at maintained non-special schools we obtained 2001-02 Scottish LA data (from SE 2003b, Table for Primary Pupils). For pupils at independent non-special schools, we obtained data for 2003 for those aged 5-11 (from SE 2004, Table 5); we assumed that the same numbers applied to 2001-02, and that the same proportion of these pupils were aged 5-10 as arises in maintained schools. For both maintained and independent schools, the same sources also give numbers of pupils at special schools, but they do not break these numbers down by age; we assumed that the proportion aged 5-10 equalled our estimated proportion of pupils aged 5-10 at non-special schools.

\section{Notes}

1 All the data in Section I derive from HM Treasury, 2004, Table 6.7, 8.9a and A11.

2 See Bell et al (1996) for further details of the origins of the Barnett formula.

3 We ignore the tiny components of the EPCS FSS that relate to flood defence, Environment Agency levies and coast protection. These account for less than $0.5 \%$ of the total EPC FSS, so their omission is not significant. 


\section{References}

BBC News, 2001 (8 May)

http://news.bbc.co.uk/vote2001/hi/english/scotland/newsid_1319000/1319894.stm

Bell, D. N. F., S. C. Dow, D. N. King and N. Massie, 1996, 'Financing Devolution', Hume Papers on Public Policy, 4/2 (Edinburgh: the David Hume Institute).

Department for Transport, 2004, Road lengths in Great Britain: 2003 Scotland Government Office Region http://www.dft.gov.uk/stellent/groups/dft_control/documents/ contentservertemplate/dft_index.hcst?n=8241\&l=5

DWP, 2002, Department for Work and Pensions Jobseeker's Allowance: Quarterly Statistical Enquiry: August 2002 http://www.dwp.gov.uk/asd/asd1/jsa/jsa_qse_aug02/jsa_aug2002_pub.pdf

DWP, 2005a, Department for Work and Pensions Income Support at August 2001 by Local Authorities/Unitary Authorities in Scotland http://www.dwp.gov.uk/asd/asd1/neighbourhood/2001/is2001_Scotland.xls

DWP, 2005b, Department for Work and Pensions Income Support at August 2002 by Local Authorities/Unitary Authorities in Scotland http://www.dwp.gov.uk/asd/asd1/neighbourhood/2002/is2002_Scotland.xls

DWP, 2005c, Department for Work and Pensions Jobseeker's Allowance at August 2002 by Local Authorities/Unitary Authorities in Scotland http://www.dwp.gov.uk/asd/asd1/neighbourhood/2001/jsa2001_all_Scotland.xls

DWP, 2005d, Department for Work and Pensions Neighbourhood Statistics - Ward Level Benefits Data: 2001 http://www.dwp.gov.uk/asd/asd1/neighbourhood/neighbourhood_2001.asp

GROS, 1993, General Register Office for Scotland, 1991 Census (Edinburgh: HMSO, published in numerous regional volumes.)

GROS, 2002, General Register Office for Scotland, Tables of Mid-2002 Population Estimates, Scotland, http://www.gro-scotland.gov.uk/statistics/library/poptest/02-mid-yearest/02-mid-year-tables.html.

HM Treasury, 2004, Public Expenditure: Statistical Analyses 2004, http://www.hmtreasury.gov.uk/media/D27/4A/pesa04_complete_190404.pdf

King, D. N., 1984, Fiscal Tiers: the Economics of Multi-level Government (London, Allen \& Unwin).

King D. N., M. Pashley and R. Ball, 2004, 'An English Assessment of Scotland's Education Spending Needs’ Fiscal Studies 25/4. 
King D. N., M. Pashley and R. Ball, 2006, Scotland's Social Services Spending Needs: an English View, working paper, University of Stirling.

Meteorological Office, 2005, 1971-2000 Mapped Averages

http://www.metoffice.gov.uk/climate/uk/averages/19712000/mapped.html

National Statistics, 2003, Transport Statistics Bulletin: Regional Transport Statistics: 2003 http://www.dft.gov.uk/stellent/groups/dft_transstats/documents/page/dft_transstats_025856.h csp

National Statistics, 2004, Annual Abstract of Statistics 2004, London: The Stationery Office.

National Statistics, 2005a, Census 2001

http://www.statistics.gov.uk/StatBase/Expodata/Spreadsheets/D6582.xls

National Statistics, 2005b, Neighbourhood Statistics, http://neighbourhood.statistics.gov.uk (using detailed information by subject on economic deprivation).

National Statistics, 2005c, Neighbourhood Statistics, http://neighbourhood.statistics.gov.uk (using detailed information by subject on work deprivation).

NES, 2000, New Earnings Survey 2000 Part E: Analyses by Region, County and Small Areas (London: The Stationery Office).

NES, 2001, New Earnings Survey 2001

http://www.statistics.gov.uk/downloads/theme_labour/NES2001_GB/NES2001_Streamlined _analyses.pdf

NES, 2002, New Earnings Survey 2002

http://www.statistics.gov.uk/downloads/theme_labour/NES2002_GB/NES2002_Streamlined _analyses.pdf

ODPM, 2002, Office of the Deputy Prime Minister, Statement on Local Government Finance in England, 2003-04, 5 December 2002.

ODPM, 2004a, Office of the Deputy Prime Minister, The Local Government Finance Report (England) 2004/2005 (London: The Stationery Office).

ODPM, 2004b, Office of the Deputy Prime Minister, Local Government Finance 2004/05

RSG Settlement Individual Local Authority Tables

http://www.local.odpm.gov.uk/finance/0405/tabs045.htm

ODPM, 2004c, Office of the Deputy Prime Minister, Local Government Finance Settlement 2005/06 http://www.local.odpm.gov.uk/finance/0506/grant.htm (under Formula Spending Shares by Sub-block).

ODPM, 2004d, Parliamentary Pack

http://www.local.odpm.gov.uk/finance/0405/keytabs/keytab1.xls 
Office of Population Censuses and Surveys, 1991, Leisure Day Visits in Great Britain 1988/99 (London: HMSO).

OS, 2005, Ordnance Survey GeoFacts: the Coastline

http://www.ordnancesurvey.co.uk/oswebsite/freefun/geofacts/coastlinelengthofgb.html

Scotexchange, 2003, Know Your Market

http://www.scotexchange.net/know_your_market.htm

Scottish Parliament, 2002, An Introduction to Local Government Finance, Scottish Parliament Information Centre Devolved Area Series 99/03.

SE, 2000, Scottish Executive Grant Aided Expenditure 2001-02(The Green book) (supplied to us by the Executive.

SE, 2001a, Scottish Executive A Coastal Management Trust for Scotland: a Concept Development and Feasibility Study http://www.scotland.gov.uk/cru/kd01/purple/ctrust00.htm

SE, 2001b, Scottish Executive Scotland's People: Results from the 1999/2000 Scottish Household Survey Volume 3: Annual Report http://www.scotland.gov.uk/stats/bulletins/00115/00115a-03.asp

SE, 2002, Scottish Executive Scottish Household Survey Bulletin No. 8 http://www.scotland.gov.uk/library5/housing/shs8-03.asp

SE, 2003a, Scottish Executive Attendance and Absence in Scottish Schools 2002/03 http://www.scotland.gov.uk/stats/bulletins/00304-03.asp\#bt5a

SE, 2003b, Scottish Executive Pupils in Scotland 2003 http://www.scotland.gov.uk/stats/pupilteachernumbers.xls

SE, 2003c, Scottish Executive Scotland's People: Results from the 2003 Scottish Household Survey Annual Report. http://www.scotland.gov.uk/library5/housing/shsar03-07.asp

SE, 2003d, Scottish Executive 2004-05 GAE Summary of Assessments (supplied by Craig Flunkert from the SE).

SE Scottish Executive, 2004, Independent School Census, September 2003 http://www.scotland.gov.uk/stats/bulletins/00340-00.asp

SE Scottish Executive, 2005a, 2002 Based Household Estimates and Projections http://www.scotland.gov.uk/about/DD/EAS/00014844/2002est_proj.aspx

SE, 2005b, Scottish Executive Claimant Count Unemployment http://www.scotland.gov.uk/about/ELLD/EI/00015648/page1398853128.aspx

Scottish Office, 1998, The Scottish Environment Statistics - 1998 http://www.scotland.gov.uk/library/stat-ses/sest2-1.htm 
SCROL, 2005, Scotland's Census Results OnLine, Scrol Analyser, http://www.scrol.gov.uk/scrol/common/home.jsp

Twigger, R., 1998, The Barnett Formula, House of Commons Research Paper 98/8. 
Table 1 The FSS factors for three groups of environmental services, England, 200405

\begin{tabular}{|l|l|l|}
\hline Fire services & Highway maintenance & EPCS \\
\hline LA costs, chiefly labour & LA costs, chiefly labour & LA costs, chiefly labour \\
\hline Population & Daytime population & Population \\
\hline People on specified benefits & Total road length & People on specified benefits \\
\hline No. of non-detached homes & Road length in built-up areas & Commuters and day visitors \\
\hline No. of homes built 1919-44 & Traffic flow & People not born in UK \\
\hline Household composition & Winter maintenance & Sparsely populated areas \\
\hline No. of rented homes & & Densely populated areas \\
\hline Primary school absences & & \\
\hline High risk properties & & \\
\hline Coastline length & & \\
\hline
\end{tabular}

Source: ODPM (2004a). 


\section{Table 2 The main indicators for GAE for EPCS, Scotland}

Adjusted population (residents, tourists \& commuters)

Dwellings and non-domestic rateable subjects

People outwith settlements of 10,000+ people

Housing Benefit and Council Tax caseload

People outwith settlements of 1,000+ people

Burial ground hectares

Distance of people outwith settlements of 7,000+ to such settlements

Deprived districts (ones with much overcrowding, high unemployment, much permanent

sickness, or many 1-parent families or large households)

Building control warrants

Cremations and interments per hectare

Source: SE (2000, Tables A-F). 
Table 3 FSS for Environmental, Protective and Cultural Services, 2004-05: Part A

\begin{tabular}{|c|c|c|c|c|c|c|c|}
\hline & $\begin{array}{r}\text { Basic } \\
\text { amoun } \\
\mathbf{t} \\
\mathbf{E} \text { per } \\
\text { head } \\
\end{array}$ & 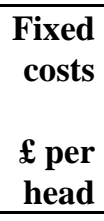 & $\begin{array}{r}\begin{array}{r}\text { Sum for } \\
\text { density }\end{array} \\
\text { E per } \\
\text { head }\end{array}$ & $\begin{array}{r}\text { Sum for } \\
\text { sparsity } \\
\text { E per } \\
\text { head }\end{array}$ & $\begin{array}{r}\text { Sum for net } \\
\text { in-commuters } \\
\text { E per } \\
\text { head } \\
\end{array}$ & 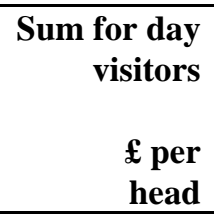 & $\begin{array}{r}\text { Total for } \\
\text { this table } \\
\text { E per } \\
\text { head }\end{array}$ \\
\hline England & 121.04 & 2.35 & 40.29 & 2.35 & 2.45 & 3.74 & 172.21 \\
\hline Westminster & 121.04 & 1.57 & 130.92 & 0.24 & 132.08 & 50.39 & 436.24 \\
\hline Liverpool & 121.04 & 0.68 & 54.67 & 0.36 & 7.51 & 5.35 & 189.60 \\
\hline Leicester & 121.04 & 1.06 & 53.86 & 0.31 & 10.94 & 4.37 & 191.58 \\
\hline Stockport & 121.04 & 1.06 & 34.25 & 0.69 & 0.00 & 4.04 & 161.08 \\
\hline Bromley & 121.04 & 1.01 & 35.28 & 1.29 & 0.00 & 3.13 & 161.75 \\
\hline Wokingham & 121.04 & 1.98 & 23.83 & 3.60 & 0.00 & 2.06 & 152.51 \\
\hline Scotland & 121.04 & 1.90 & 44.56 & 6.31 & 3.27 & 2.69 & 179.77 \\
\hline Aberdeen City & 121.04 & 1.43 & 53.02 & 1.53 & 15.94 & 2.17 & 195.13 \\
\hline Aberdeenshire & 121.04 & 1.32 & 20.15 & 19.09 & 0.00 & 2.17 & 163.77 \\
\hline Angus & 121.04 & 2.77 & 27.58 & 11.80 & 0.00 & 1.09 & 164.29 \\
\hline Argyll \& Bute & 121.04 & 3.30 & 20.07 & 17.89 & 0.00 & 2.05 & 164.34 \\
\hline Clackmannanshire & 121.04 & 6.26 & 33.05 & 3.46 & 0.00 & 2.05 & 165.86 \\
\hline $\begin{array}{l}\text { Dumfries \& } \\
\text { Galloway }\end{array}$ & 121.04 & 2.04 & 20.63 & 18.59 & 0.00 & 4.27 & 166.56 \\
\hline Dundee City & 121.04 & 2.08 & 67.68 & 0.54 & 6.97 & 1.09 & 199.41 \\
\hline East Ayrshire & 121.04 & 2.51 & 31.99 & 5.78 & 0.00 & 2.78 & 164.10 \\
\hline East Dunbartonshire & 121.04 & 2.80 & 33.54 & 1.92 & 0.00 & 2.29 & 161.58 \\
\hline East Lothian & 121.04 & 3.31 & 36.06 & 6.91 & 0.00 & 2.51 & 169.82 \\
\hline East Renfrewshire & 121.04 & 3.35 & 34.67 & 1.59 & 0.00 & 2.29 & 162.94 \\
\hline Edinburgh, City of & 121.04 & 0.67 & 73.96 & 0.89 & 9.55 & 5.03 & 211.15 \\
\hline Eilean Siar & 121.04 & 11.45 & 5.93 & 40.82 & 0.00 & 1.20 & 180.45 \\
\hline Falkirk & 121.04 & 2.06 & 37.00 & 2.71 & 0.00 & 2.05 & 164.86 \\
\hline Fife & 121.04 & 0.86 & 32.84 & 4.30 & 0.00 & 2.93 & 161.96 \\
\hline Glasgow, City of & 121.04 & 0.52 & 95.87 & 0.52 & 13.22 & 2.29 & 233.45 \\
\hline Highland & 121.04 & 1.44 & 18.28 & 20.69 & 0.00 & 1.20 & 162.65 \\
\hline Inverclyde & 121.04 & 3.59 & 49.45 & 1.58 & 0.00 & 2.29 & 177.95 \\
\hline Midlothian & 121.04 & 3.73 & 36.39 & 4.60 & 0.00 & 2.51 & 168.26 \\
\hline Moray & 121.04 & 3.46 & 24.00 & 12.94 & 0.00 & 2.17 & 163.60 \\
\hline North Ayrshire & 121.04 & 2.21 & 33.44 & 4.34 & 0.00 & 2.78 & 163.81 \\
\hline North Lanarkshire & 121.04 & 0.93 & 46.91 & 1.85 & 0.00 & 2.29 & 173.02 \\
\hline Orkney Islands & 121.04 & 15.62 & 10.53 & 37.23 & 0.00 & 1.20 & 185.63 \\
\hline Perth \& Kinross & 121.04 & 2.22 & 22.75 & 14.09 & 0.00 & 6.56 & 166.66 \\
\hline Renfrewshire & 121.04 & 1.74 & 43.95 & 1.72 & 0.00 & 2.29 & 170.74 \\
\hline Scottish Borders & 121.04 & 2.79 & 23.76 & 17.34 & 0.00 & 3.50 & 168.44 \\
\hline Shetland Islands & 121.04 & 13.67 & 10.65 & 37.56 & 0.17 & 1.20 & 184.30 \\
\hline South Ayrshire & 121.04 & 2.69 & 30.44 & 5.93 & 0.93 & 2.78 & 163.81 \\
\hline South Lanarkshire & 121.04 & 0.99 & 29.09 & 4.04 & 0.00 & 2.56 & 157.72 \\
\hline Stirling & 121.04 & 3.48 & 29.08 & 8.86 & 1.91 & 2.05 & 166.42 \\
\hline West Dunbartonshire & 121.04 & 3.23 & 48.57 & 1.65 & 0.00 & 2.05 & 176.54 \\
\hline West Lothian & 121.04 & 1.88 & 35.27 & 3.14 & 0.00 & 2.51 & 163.84 \\
\hline
\end{tabular}


Table 4 FSS for Environmental, Protective and Cultural Services, 2004-05: Part B

\begin{tabular}{|c|c|c|c|c|c|c|c|}
\hline & $\begin{array}{r}\text { Sum for } \\
\text { IB and } \\
\text { SDA } \\
\\
\text { E per } \\
\text { head } \\
\end{array}$ & 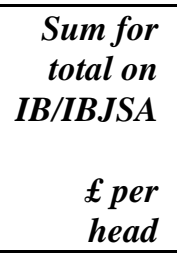 & $\begin{array}{r}\text { Sum for } \\
\text { elderly on } \\
\text { IB/IBJSA } \\
\\
\text { E per } \\
\text { head } \\
\end{array}$ & $\begin{array}{r}\begin{array}{r}\text { Sum for un- } \\
\text { employment } \\
\text { related benefits }\end{array} \\
\text { E per } \\
\text { head }\end{array}$ & $\begin{array}{r}\begin{array}{r}\text { Sum for } \\
\text { country } \\
\text { of birth }\end{array} \\
\text { E per } \\
\text { head } \\
\end{array}$ & $\begin{array}{r}\text { ACA less } \\
\text { London } \\
\text { adjustmen } \\
t \\
\text { E per } \\
\text { head } \\
\end{array}$ & $\begin{array}{r}\text { Total FSS } \\
\text { (after } \\
\text { scaling) } \\
\\
\text { E per } \\
\text { head } \\
\end{array}$ \\
\hline England & 8.79 & 23.64 & 3.72 & 5.46 & 2.96 & 6.96 & 223.71 \\
\hline Westminster & 9.40 & 31.86 & 4.06 & 8.13 & 14.39 & 70.45 & 574.47 \\
\hline Liverpool & 21.30 & 55.05 & 6.89 & 12.89 & 11.95 & 2.91 & 300.57 \\
\hline Leicester & 10.85 & 35.86 & 5.44 & 9.48 & 10.96 & 0.00 & 264.16 \\
\hline Stockport & 8.77 & 20.31 & 3.64 & 3.62 & 1.41 & 3.62 & 202.44 \\
\hline Bromley & 5.38 & 16.62 & 2.52 & 4.02 & 3.03 & 1.79 & 195.11 \\
\hline Wokingham & 2.97 & 6.90 & 1.34 & 1.65 & 2.44 & 18.69 & 186.49 \\
\hline Scotland & 13.35 & 29.70 & 4.47 & 7.16 & 0.95 & 2.72 & 238.09 \\
\hline Aberdeen City & 10.10 & 22.55 & 3.53 & 4.52 & 1.44 & 0.00 & 237.26 \\
\hline Aberdeenshire & 6.85 & 14.43 & 2.83 & 3.01 & 0.83 & 13.74 & 205.43 \\
\hline Angus & 8.55 & 23.57 & 4.13 & 6.77 & 0.69 & 0.00 & 207.98 \\
\hline Argyll \& Bute & 9.60 & 23.48 & 4.14 & 6.70 & 0.63 & 0.00 & 208.88 \\
\hline Clackmannanshire & 15.81 & 29.31 & 3.68 & 8.13 & 0.82 & 0.00 & 223.58 \\
\hline $\begin{array}{l}\text { Dumfries \& } \\
\text { Galloway }\end{array}$ & 10.03 & 24.68 & 4.36 & 6.85 & 0.62 & 0.00 & 213.10 \\
\hline Dundee City & 15.37 & 41.18 & 5.76 & 11.15 & 1.51 & 0.00 & 274.34 \\
\hline East Ayrshire & 13.97 & 34.93 & 5.13 & 10.32 & 0.43 & 0.00 & 228.87 \\
\hline East Dunbartonshire & 9.51 & 15.69 & 2.68 & 4.30 & 1.48 & 0.00 & 195.23 \\
\hline East Lothian & 9.51 & 20.54 & 3.89 & 3.42 & 0.70 & 0.00 & 207.87 \\
\hline East Renfrewshire & 8.77 & 15.56 & 2.61 & 3.84 & 0.76 & 0.00 & 194.46 \\
\hline Edinburgh, City of & 10.04 & 23.78 & 3.19 & 5.37 & 1.77 & 16.12 & 271.40 \\
\hline Eilean Siar & 9.28 & 35.21 & 8.80 & 9.62 & 0.54 & 0.00 & 243.88 \\
\hline Falkirk & 13.43 & 27.49 & 4.34 & 7.51 & 0.60 & 0.00 & 218.22 \\
\hline Fife & 10.87 & 25.11 & 3.34 & 8.29 & 0.84 & 0.00 & 210.39 \\
\hline Glasgow, City of & 24.03 & 55.67 & 7.50 & 10.79 & 1.64 & 5.91 & 338.95 \\
\hline Highland & 9.45 & 23.93 & 4.13 & 7.14 & 0.82 & 0.00 & 208.10 \\
\hline Inverclyde & 19.29 & 40.35 & 5.94 & 9.10 & 0.47 & 0.00 & 253.09 \\
\hline Midlothian & 11.05 & 20.69 & 3.08 & 3.89 & 0.66 & 0.00 & 207.61 \\
\hline Moray & 7.89 & 18.78 & 3.33 & 5.19 & 0.76 & 0.00 & 199.54 \\
\hline North Ayrshire & 14.79 & 35.95 & 4.87 & 10.94 & 0.49 & 0.00 & 230.83 \\
\hline North Lanarkshire & 19.74 & 35.42 & 5.10 & 8.09 & 0.43 & 0.00 & 241.78 \\
\hline Orkney Islands & 7.26 & 16.21 & 3.39 & 4.34 & 0.51 & 0.00 & 217.32 \\
\hline Perth \& Kinross & 7.77 & 18.90 & 3.61 & 4.26 & 0.89 & 0.00 & 202.07 \\
\hline Renfrewshire & 15.54 & 31.68 & 4.57 & 7.50 & 0.76 & 0.00 & 230.77 \\
\hline Scottish Borders & 7.34 & 19.56 & 3.78 & 4.44 & 0.76 & 0.00 & 204.29 \\
\hline Shetland Islands & 6.21 & 15.04 & 3.22 & 4.01 & 0.75 & 0.00 & 213.51 \\
\hline South Ayrshire & 11.67 & 27.59 & 4.35 & 8.04 & 0.63 & 0.00 & 216.07 \\
\hline South Lanarkshire & 15.95 & 30.41 & 4.95 & 6.52 & 0.40 & 0.00 & 215.94 \\
\hline Stirling & 10.76 & 21.53 & 3.39 & 5.36 & 0.96 & 0.00 & 208.40 \\
\hline West Dunbartonshire & 16.89 & 42.62 & 6.18 & 10.89 & 0.63 & 0.00 & 253.75 \\
\hline West Lothian & 12.11 & 25.43 & 3.72 & 6.31 & 0.66 & 0.00 & 212.06 \\
\hline
\end{tabular}


Table 5 FSS for Highway Maintenance, 2004-05

\begin{tabular}{|c|c|c|c|c|c|c|c|}
\hline & $\begin{array}{r}\text { Un- } \\
\text { weighted } \\
\text { road } \\
\text { length } \\
\text { miles } \\
\text { per head } \\
\end{array}$ & $\begin{array}{r}\text { Sum for } \\
\text { weighted } \\
\text { road } \\
\text { length } \\
\text { E per } \\
\text { head } \\
\end{array}$ & $\begin{array}{r}\text { Sum for } \\
\text { traffic } \\
\text { flow } \\
\text { top-up } \\
\text { E per } \\
\text { head }\end{array}$ & $\begin{array}{r}\text { Sum for } \\
\text { day-time } \\
\text { population } \\
\text { top-up } \\
\text { E per } \\
\text { head }\end{array}$ & $\begin{array}{r}\text { Sum for } \\
\text { winter } \\
\text { maintenance } \\
\text { top-up } \\
\text { E per } \\
\text { head } \\
\end{array}$ & 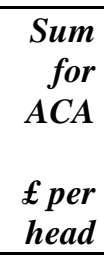 & 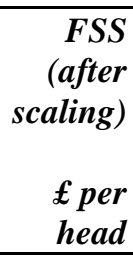 \\
\hline England & 5.74 & 3.63 & 20.37 & 11.58 & 3.34 & 1.49 & 40.43 \\
\hline Westminster & 1.77 & 1.46 & 21.07 & 45.21 & 0.95 & 16.00 & 84.70 \\
\hline North Yorkshire & 15.64 & 7.89 & 28.06 & 7.58 & 9.65 & 0.00 & 53.19 \\
\hline Liverpool & 3.22 & 2.65 & 27.45 & 13.31 & 1.78 & 0.43 & 45.63 \\
\hline Northumberland & 15.96 & 8.26 & 22.81 & 7.52 & 9.46 & 0.00 & 48.07 \\
\hline Cumbria & 14.91 & 7.54 & 15.55 & 7.57 & 8.68 & 0.00 & 39.35 \\
\hline Isle of Wight & 6.36 & 4.09 & 12.52 & 10.30 & 2.33 & 1.17 & 30.40 \\
\hline Scotland & 11.12 & 6.17 & 19.57 & 9.97 & 7.48 & 0.53 & 43.72 \\
\hline Aberdeen City & 4.61 & 3.49 & 27.26 & 13.37 & 4.14 & 0.00 & 48.26 \\
\hline Aberdeenshire & 28.49 & 13.43 & 22.32 & 6.69 & 18.71 & 4.38 & 65.53 \\
\hline Angus & 18.41 & 9.24 & 24.68 & 6.94 & 13.51 & 0.00 & 54.38 \\
\hline Argyll \& Bute & 29.20 & 13.99 & 10.46 & 6.92 & 13.06 & 0.00 & 44.45 \\
\hline Clackmannanshire & 6.08 & 4.17 & 15.66 & 9.90 & 4.93 & 0.00 & 34.66 \\
\hline Dumfries \& & 29.86 & 13.68 & 13.37 & 6.87 & 13.59 & 0.00 & 47.53 \\
\hline \multicolumn{8}{|l|}{ Galloway } \\
\hline Dundee City & 3.68 & 2.89 & 15.27 & 12.05 & 3.07 & 0.00 & 33.27 \\
\hline East Ayrshire & 10.50 & 5.94 & 24.65 & 8.03 & 6.46 & 0.00 & 45.08 \\
\hline East Dunbartonshire & 4.78 & 3.47 & 14.18 & 10.14 & 4.08 & 0.00 & 31.87 \\
\hline East Lothian & 11.02 & 6.10 & 14.80 & 7.73 & 6.11 & 0.00 & 34.75 \\
\hline East Renfrewshire & 5.31 & 3.93 & 24.23 & 10.36 & 4.48 & 0.00 & 43.01 \\
\hline Edinburgh, City of & 3.18 & 2.52 & 26.23 & 13.75 & 2.64 & 2.84 & 47.98 \\
\hline Eilean Siar & 48.05 & 20.74 & 9.66 & 6.44 & 19.16 & 0.00 & 56.00 \\
\hline Falkirk & 5.93 & 4.05 & 18.57 & 9.87 & 4.07 & 0.00 & 36.57 \\
\hline Fife & 7.50 & 4.94 & 18.36 & 9.32 & 4.85 & 0.00 & 37.48 \\
\hline Glasgow, City of & 3.05 & 2.49 & 20.28 & 13.75 & 2.36 & 0.68 & 39.57 \\
\hline Highland & 35.45 & 16.55 & 6.93 & 6.96 & 25.36 & 0.00 & 55.82 \\
\hline Inverclyde & 4.69 & 3.45 & 27.14 & 10.29 & 3.77 & 0.00 & 44.66 \\
\hline Midlothian & 7.35 & 4.46 & 18.06 & 8.49 & 5.56 & 0.00 & 36.58 \\
\hline Moray & 20.34 & 10.25 & 14.49 & 7.15 & 15.20 & 0.00 & 47.10 \\
\hline North Ayrshire & 7.99 & 4.99 & 8.80 & 8.88 & 5.10 & 0.00 & 27.77 \\
\hline North Lanarkshire & 4.84 & 3.57 & 27.18 & 10.32 & 4.11 & 0.00 & 45.19 \\
\hline Orkney Islands & 57.51 & 26.15 & 17.42 & 6.78 & 27.88 & 0.00 & 78.25 \\
\hline Perth \& Kinross & 20.73 & 11.67 & 21.88 & 8.79 & 17.78 & 0.00 & 60.13 \\
\hline Renfrewshire & 5.02 & 3.64 & 19.38 & 10.14 & 3.55 & 0.00 & 36.71 \\
\hline Scottish Borders & 28.48 & 13.05 & 18.03 & 6.68 & 17.09 & 0.00 & 54.85 \\
\hline Shetland Islands & 46.88 & 20.65 & 16.52 & 6.59 & 24.95 & 0.00 & 68.72 \\
\hline South Ayrshire & 11.03 & 6.17 & 14.41 & 8.06 & 5.92 & 0.00 & 34.57 \\
\hline South Lanarkshire & 7.79 & 4.82 & 18.54 & 8.65 & 6.47 & 0.00 & 38.49 \\
\hline Stirling & 12.48 & 6.96 & 19.21 & 8.29 & 9.50 & 0.00 & 43.96 \\
\hline West Dunbartonshire & 4.18 & 3.20 & 14.54 & 11.06 & 3.41 & 0.00 & 32.22 \\
\hline West Lothian & 6.53 & 4.37 & 20.36 & 9.35 & 4.95 & 0.00 & 39.04 \\
\hline
\end{tabular}


Table 6 FSS for Fire Services, 2004-05: Part A

\begin{tabular}{|c|c|c|c|c|c|}
\hline Basic & Sum for & um for non- & Sum for & Sum for & Sum for \\
\hline amount & $\begin{array}{r}\text { IS/IBJSA } \\
\text { dependants }\end{array}$ & $\begin{array}{r}\text { detached } \\
\text { homes }\end{array}$ & $\begin{array}{r}1919-44 \\
\text { homes }\end{array}$ & $\begin{array}{r}\text { household } \\
\text { composition }\end{array}$ & $\begin{array}{r}\text { people } \\
\text { who rent }\end{array}$ \\
\hline$£$ per head & $£$ per head & $£$ per head & $£$ per head & $£$ per head & $£$ per head \\
\hline
\end{tabular}

\begin{tabular}{lrrrrrrr}
\hline England & & & & & & & \\
Isles of Scilly & $\mathbf{1 8 . 0 3}$ & $\mathbf{1 . 5 0}$ & $\mathbf{1 . 0 0}$ & $\mathbf{1 . 0 0}$ & $\mathbf{1 . 0 0}$ & $\mathbf{1 . 0 0}$ & $\mathbf{1 . 5 0}$ \\
Isle of Wight & 18.03 & 0.21 & 0.43 & 0.39 & 0.16 & 0.62 & 2.70 \\
London & 18.03 & 1.51 & -0.10 & 0.54 & 0.56 & 0.41 & 1.55 \\
Cornwall & 18.03 & 2.21 & 1.77 & 1.86 & 1.90 & 1.95 & 2.20 \\
Lincolnshire & 18.03 & 1.27 & 0.43 & 0.39 & 0.16 & 0.62 & 1.70 \\
& 18.03 & 1.08 & 0.05 & 0.42 & 0.46 & 0.76 & 0.84 \\
Scotland & & & & & & & \\
Central & $\mathbf{1 8 . 0 3}$ & $\mathbf{1 . 5 4}$ & $\mathbf{1 . 0 5}$ & $\mathbf{0 . 7 5}$ & $\mathbf{1 . 2 2}$ & $\mathbf{1 . 6 1}$ & $\mathbf{0 . 6 5}$ \\
Dumfries \& Galloway & 18.03 & 1.32 & 1.00 & 0.75 & 1.07 & 1.71 & 0.33 \\
Fife & 18.03 & 1.13 & 0.52 & 0.75 & 0.62 & 1.54 & -0.34 \\
Grampian & 18.03 & 1.39 & 1.03 & 0.75 & 0.93 & 1.53 & 0.78 \\
Highland \& Islands & 18.03 & 0.97 & 0.60 & 0.75 & 0.89 & 1.37 & -0.12 \\
Lothian \& Borders & 18.03 & 1.06 & 0.00 & 0.75 & 0.99 & 1.25 & -0.13 \\
Strathclyde & 18.03 & 1.31 & 1.19 & 0.75 & 1.10 & 1.43 & 0.49 \\
Tayside & 18.03 & 1.92 & 1.32 & 0.75 & 1.53 & 1.78 & 1.13 \\
& 18.03 & 1.41 & 0.84 & 0.75 & 0.97 & 1.66 & 0.40 \\
\hline & & & & & & & \\
\hline
\end{tabular}


Table 7 FSS for Fire Services, 2004-05: Part B

\begin{tabular}{|c|c|c|c|c|c|c|c|}
\hline & $\begin{array}{r}\text { Sum for } \\
\text { 'A risk' } \\
\text { areas } \\
\text { £ per } \\
\text { head }\end{array}$ & $\begin{array}{r}\text { Sum for } \\
\text { certificatabl } \\
\text { e premises } \\
\text { £ per } \\
\text { head }\end{array}$ & $\begin{array}{r}\text { Sum for } \\
\text { fire } \\
\text { safety } \\
\text { E per } \\
\text { head } \\
\end{array}$ & $\begin{array}{r}\text { Sum for } \\
\text { coastline }^{\mathrm{a}} \\
\\
\text { E per } \\
\text { head } \\
\end{array}$ & $\begin{array}{r}\text { Sum for } \\
\text { ACA } \\
\\
\text { E per } \\
\text { head }\end{array}$ & $\begin{array}{r}\text { Sum for } \\
\text { fire } \\
\text { pensions } \\
\text { E per } \\
\text { head } \\
\end{array}$ & $\begin{array}{r}\text { Total FSS } \\
\text { (after } \\
\text { scaling) } \\
\text { E per head }\end{array}$ \\
\hline England & 0.69 & 2.30 & 1.05 & 0.56 & 1.63 & 5.96 & 37.28 \\
\hline Isles of Scilly & 0.00 & 10.27 & 0.50 & 184.57 & 0.00 & 0.00 & 218.29 \\
\hline Isle of Wight & 0.00 & 3.75 & 0.78 & 6.84 & 1.63 & 7.16 & 42.74 \\
\hline London & 0.56 & 2.74 & 1.56 & 0.00 & 6.57 & 9.27 & 50.72 \\
\hline Cornwall & 0.00 & 2.84 & 0.77 & 9.01 & 0.00 & 3.83 & 39.13 \\
\hline Lincolnshire & 0.00 & 1.44 & 0.80 & 2.03 & 0.00 & 3.20 & 29.17 \\
\hline Scotland & 0.81 & 1.21 & 1.06 & 11.57 & 0.39 & 8.40 & 48.40 \\
\hline Central & 0.00 & 1.02 & 1.08 & 1.45 & 0.00 & 7.24 & 35.06 \\
\hline $\begin{array}{l}\text { Dumfries \& } \\
\text { Galloway }\end{array}$ & 0.00 & 0.93 & 1.05 & 14.14 & 0.00 & 8.68 & 47.13 \\
\hline Fife & 0.00 & 0.78 & 1.05 & 2.68 & 0.00 & 14.54 & 43.57 \\
\hline Grampian & 0.13 & 1.36 & 1.05 & 3.10 & 1.08 & 5.65 & 34.93 \\
\hline Highland \& Islands & 0.00 & 1.56 & 1.08 & 138.29 & 0.00 & 3.01 & 166.20 \\
\hline Lothian \& Borders & 0.69 & 1.28 & 1.04 & 0.86 & 1.12 & 6.16 & 35.52 \\
\hline Strathclyde & 1.12 & 1.23 & 1.08 & 6.29 & 0.19 & 9.22 & 45.67 \\
\hline Tayside & 2.51 & 1.14 & 1.05 & 1.84 & 0.00 & 11.61 & 42.30 \\
\hline
\end{tabular}

a See the text for a discussion of the figures for Scotland and the individual Scottish fire authorities. 
Table 8 FSS and GAE for Roads, Environmental, Protective and Cultural Services, 2004-05

\begin{tabular}{|c|c|c|c|c|c|c|c|c|}
\hline & $\begin{array}{r}\text { FSS } \\
\text { for } \\
\text { EPCS } \\
\text { E per } \\
\text { head }\end{array}$ & $\begin{array}{r}\text { GAE } \\
\text { for } \\
\text { EPCS } \\
\text { E per } \\
\text { head } \\
\end{array}$ & $\begin{array}{r}\text { Relative } \\
\text { EPCS } \\
\text { FSS } \\
\text { per } \\
\text { head } \\
\end{array}$ & $\begin{array}{r}\text { Relative } \\
\text { EPCS } \\
\text { GAE } \\
\text { per } \\
\text { head } \\
\end{array}$ & $\begin{array}{r}\text { FSS for } \\
\text { highway } \\
\text { maint'ce } \\
\text { E per } \\
\text { head }\end{array}$ & $\begin{array}{r}G A E \\
\text { for } \\
\text { roads } \\
\text { E per } \\
\text { head } \\
\end{array}$ & $\begin{array}{r}\text { Relative } \\
\text { highway } \\
\text { maint'ce } \\
\text { FSS per } \\
\text { head } \\
\end{array}$ & $\begin{array}{r}\text { Relative } \\
\text { roads } \\
\text { GAE } \\
\text { per } \\
\text { head }\end{array}$ \\
\hline Scotland & 238.09 & 233.00 & 1.00 & 1.00 & 43.72 & 54.94 & 1.00 & 1.00 \\
\hline Aberdeen City & 237.26 & 225.54 & 1.00 & 0.97 & 48.26 & 37.16 & 1.10 & 0.68 \\
\hline Aberdeenshire & 205.43 & 204.76 & 0.86 & 0.88 & 65.53 & 89.62 & 1.50 & 1.63 \\
\hline Angus & 207.98 & 217.69 & 0.87 & 0.93 & 54.38 & 66.23 & 1.24 & 1.21 \\
\hline Argyll \& Bute & 208.88 & 259.92 & 0.88 & 1.12 & 44.45 & 109.88 & 1.02 & 2.00 \\
\hline Clackmannanshire & 223.58 & 210.88 & 0.94 & 0.91 & 34.66 & 45.05 & 0.79 & 0.82 \\
\hline Dumfries \& & 213.10 & 231.81 & 0.90 & 0.99 & 47.53 & 97.23 & 1.09 & 1.77 \\
\hline Galloway & & & & & & & & \\
\hline Dundee City & 274.34 & 257.70 & 1.15 & 1.11 & 33.27 & 32.21 & 0.76 & 0.59 \\
\hline East Ayrshire & 228.87 & 213.41 & 0.96 & 0.92 & 45.08 & 48.36 & 1.03 & 0.88 \\
\hline East Dunbartonshire & 195.23 & 206.18 & 0.82 & 0.88 & 31.87 & 41.68 & 0.73 & 0.76 \\
\hline East Lothian & 207.87 & 196.85 & 0.87 & 0.84 & 34.75 & 51.24 & 0.79 & 0.93 \\
\hline East Renfrewshire & 194.46 & 196.64 & 0.82 & 0.84 & 43.01 & 41.46 & 0.98 & 0.75 \\
\hline Edinburgh, City of & 271.40 & 223.38 & 1.14 & 0.96 & 47.98 & 37.68 & 1.10 & 0.69 \\
\hline Eilean Siar & 243.88 & 449.68 & 1.02 & 1.93 & 56.00 & 238.69 & 1.28 & 4.34 \\
\hline Falkirk & 218.22 & 208.28 & 0.92 & 0.89 & 36.57 & 43.76 & 0.84 & 0.80 \\
\hline Fife & 210.39 & 222.99 & 0.88 & 0.96 & 37.48 & 45.83 & 0.86 & 0.83 \\
\hline Glasgow, City of & 338.95 & 277.82 & 1.42 & 1.19 & 39.57 & 30.92 & 0.91 & 0.56 \\
\hline Highland & 208.10 & 255.32 & 0.87 & 1.10 & 55.82 & 116.86 & 1.28 & 2.13 \\
\hline Inverclyde & 253.09 & 219.44 & 1.06 & 0.94 & 44.66 & 32.99 & 1.02 & 0.60 \\
\hline Midlothian & 207.61 & 221.18 & 0.87 & 0.95 & 36.58 & 48.91 & 0.84 & 0.89 \\
\hline Moray & 199.54 & 210.73 & 0.84 & 0.90 & 47.10 & 72.65 & 1.08 & 1.32 \\
\hline North Ayrshire & 230.83 & 217.83 & 0.97 & 0.93 & 27.77 & 44.17 & 0.64 & 0.80 \\
\hline North Lanarkshire & 241.78 & 212.69 & 1.02 & 0.91 & 45.19 & 35.72 & 1.03 & 0.65 \\
\hline Orkney Islands & 217.32 & 568.63 & 0.91 & 2.44 & 78.25 & 240.69 & 1.79 & 4.38 \\
\hline Perth \& Kinross & 202.07 & 221.21 & 0.85 & 0.95 & 60.13 & 75.44 & 1.38 & 1.37 \\
\hline Renfrewshire & 230.77 & 212.15 & 0.97 & 0.91 & 36.71 & 37.80 & 0.84 & 0.69 \\
\hline Scottish Borders & 204.29 & 215.82 & 0.86 & 0.93 & 54.85 & 97.85 & 1.25 & 1.78 \\
\hline Shetland Islands & 213.51 & 728.60 & 0.90 & 3.13 & 68.72 & 244.40 & 1.57 & 4.45 \\
\hline South Ayrshire & 216.07 & 221.98 & 0.91 & 0.95 & 34.57 & 52.86 & 0.79 & 0.96 \\
\hline South Lanarkshire & 215.94 & 242.10 & 0.91 & 1.04 & 38.49 & 44.30 & 0.88 & 0.81 \\
\hline Stirling & 208.40 & 222.90 & 0.88 & 0.96 & 43.96 & 85.73 & 1.01 & 1.56 \\
\hline West Dunbartonshire & 253.75 & 213.07 & 1.07 & 0.91 & 32.22 & 33.72 & 0.74 & 0.61 \\
\hline West Lothian & 212.06 & 204.00 & 0.89 & 0.88 & 39.04 & 46.37 & 0.89 & 0.84 \\
\hline
\end{tabular}


Table 9 FSS and GAE for Fire Services, 2004-05

\begin{tabular}{|c|c|c|c|c|c|c|}
\hline & $\begin{array}{r}\text { Total FSS } \\
\text { (after scaling) } \\
\text { £ per } \\
\text { head } \\
\end{array}$ & $\begin{array}{r}\text { Total fire } \\
\text { GAE } \\
\text { E per } \\
\text { head }\end{array}$ & $\begin{array}{r}\text { Relative } \\
\text { FSS } \\
\text { per } \\
\text { head } \\
\end{array}$ & $\begin{array}{r}\text { Relative } \\
\text { GAE } \\
\text { per } \\
\text { head } \\
\end{array}$ & $\begin{array}{r}\text { Relative FSS } \\
\text { per head } \\
\text { (ignoring } \mathrm{H} \\
\text { \& Islands) } \\
\end{array}$ & $\begin{array}{r}\text { Relative GAE } \\
\text { per head } \\
\text { (ignoring } H \\
\text { \& Islands) }\end{array}$ \\
\hline Scotland & 48.40 & 49.13 & 1.00 & 1.00 & 1.00 & 1.00 \\
\hline Central & 35.06 & 47.61 & 0.72 & 0.97 & 0.84 & 0.97 \\
\hline $\begin{array}{l}\text { Dumfries \& } \\
\text { Galloway }\end{array}$ & 47.13 & 50.84 & 0.97 & 1.03 & 1.13 & 1.04 \\
\hline Fife & 43.57 & 59.43 & 0.90 & 1.21 & 1.05 & 1.21 \\
\hline Grampian & 34.93 & 40.95 & 0.72 & 0.83 & 0.84 & 0.83 \\
\hline Highland \& Islands & 166.20 & 49.54 & 3.43 & 1.01 & - & - \\
\hline Lothian \& Borders & 35.52 & 42.18 & 0.73 & 0.86 & 0.85 & 0.86 \\
\hline Strathclyde & 45.67 & 50.50 & 0.94 & 1.03 & 1.10 & 1.03 \\
\hline Tayside & 42.30 & 59.12 & 0.87 & 1.20 & 1.02 & 1.20 \\
\hline
\end{tabular}

